\title{
INCUBATION STRENGTHENING SOCIAL BUSINESS BASED ON JAVANESE-ISLAMIC CULTURE
}

\section{JISCOS}

01,2

\section{Received,}

October 2021

Revised,

November 2021

December 2021

Accepted,

December 2021

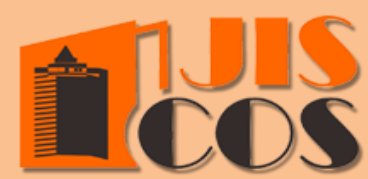

\section{CORRESPONDING AUTHOR}

Author's Name:

Ronny Ersya Novianto Putra

Institution: Univ. Brawijaya Malang

E-mail:

mygardanaindonesia@gmail.com

\author{
Ronny Ersya Novianto Putra ${ }^{1}$, Ahmad Saifullah ${ }^{2}$ \\ ${ }^{1}$ Universitas Brawijaya Malang \\ ${ }^{2}$ Universitas Brawijaya Malang
}

\begin{abstract}
This study aims to build a sustainable model for empowering Arjuno coffee farmers. This study uses a qualitative method. This study indicates that Arjuno coffee farmers adhere to Javanese-Islamic values and culture; this is the basis for describing Pre-Incubation Strengthening of Javanese-Islamic Culture-Based Social Business (ISBSBoJI). Meanwhile, ISBSBoJI was built by increasing the capability and productivity of Arjuno coffee farmers with market orientation and collaboration. The goal of PostISBSBoJI is to increase trust and sustainable welfare.
\end{abstract}

Keywords: Arjuno coffee farmers, Well Being, Empowerment Model
Cite (Harvard):

Ronny Ersya Novianto Putra, Ahmad Saifullah. (2022). Incubation Strengthening Social Business Based on Javanese-Islamic Culture. Journal of Interdisciplinary Socio-Economic and Community Study, Volume 01, Number 2, Pages 48-54. Universitas Brawijaya. DOI: http://dx.doi.org/10.21776/jiscos.01.1.01 


\section{INTRODUCTION}

Classical and neoclassical economic views view individual economic actions only to maximize profits and minimize costs or are rational and instrumental.

The view of economic sociology, borrowing Granovetter's (2005) statement that cultural and religious values can influence individuals' economic actions and form a collective economic network. The process of creating a cooperative economic network can be done by building social network relationships with economic benefits, namely: (a) norms and network density, b) the strength of weak ties, c) the importance of structural holes, and d) the interpenetration of economic and non-economic action.

In East Java coffee farming, the ArjunoBromo-Tengger-Semeru center is the most dominant, with 25,322 hectares of Arabica coffee production, 15,650 tons of Arabica coffee production per year, and 70,847 farmers. Malang Regency is the primary driver of the ArjunoBromo center. -Tengger-Semeru. It has 15,085 hectares of Arabica coffee production area, with Arabica coffee production of 10,284 tons/year and 46,313 farmers seeking Arabica coffee (Kementrian Pertanian RI, 2020).

One of the sub-districts in the ArjunoBromo-Tengger-Semeru sub-district is the Karangploso sub-district. The potential for coffee in the Karangploso sub-district is located chiefly on Perhutani land on Mount Arjuno; the coffee commodity is planted under thick vegetation of pine trees. Seventy-five percent of Arjuno coffee is arabica coffee, and 35 percent is robusta coffee. There are four potential Arjuno coffee villages: Bocek, Ngenep, Donowarih, Tawangagro villages. The four villages can produce 6.5 quintals of green beans/ha/season; geographically, the average height of the four villages is between 500-1500 masl. Farmers in four villages sell coffee in green beans, red cherry, and yellow catura (Hasil Pra-Penelitiam, 2020).

Pre-research findings illustrate that the development of Arjuno coffee for nine years, in 2013-2020, has implemented the interpenetration of economic and non-economic action.
Stakeholders outside of Arjuno coffee farmers (agricultural extension workers and social entrepreneurs) take advantage of the attachment of Javanese and Islamic moral ethics to solve problems. Coffee farmers, especially farmers' bargaining power and product quantity. Based on the scientific arguments above, this research explores the motives of socio-economic trust (Pre-Incubation Strengthening Social Business Based on Javanese-Islamic Culture). That have been formed in the coffee farming community of Arjuno, which are used to build solutions in the form of incubation for strengthening social business based on Javanese-Islamic culture.

\section{METHOD}

This research is based on a qualitative method with a case study approach. This research was conducted on the coffee farming community of Arjuno, Karangploso sub-district, Malang district. Field research was conducted in November 2020-July 2021. This study used indepth observations and interviews with time and source triangulation analysis. This research produces information in the form of a motive economic trust in the economic activities of Arjuno coffee farmers in Karangploso (an explicit form of economic benefits from the social business of Arjuno coffee). The research findings can create a model for empowering sustainable farming communities by continuing a social enterprise based on Javanese-Islamic culture.

\section{RESULTS AND DISCUSSION}

The motive of Arjuno Coffee Farmer's Economic Trust: Pre-Incubation Strengthening Social Business Based on Javanese-Islamic Culture

Granovetter (1985), (2005), taking the research results of Ostrom and Ahn (2009) socioeconomic embeddedness, which is an inseparable part of socio-economic actions that will create an economic motive of trust by considering various forms or motives of social capital found in society. Where individuals have heterogeneous preferences, what is essential is how to recognize the economic trust that is formed, defining individual choices consistent 
with the prerequisites of cooperation. Various forms of social capital contribute to the success of the trust economy actions are always carried out by increasing trust among the actors.
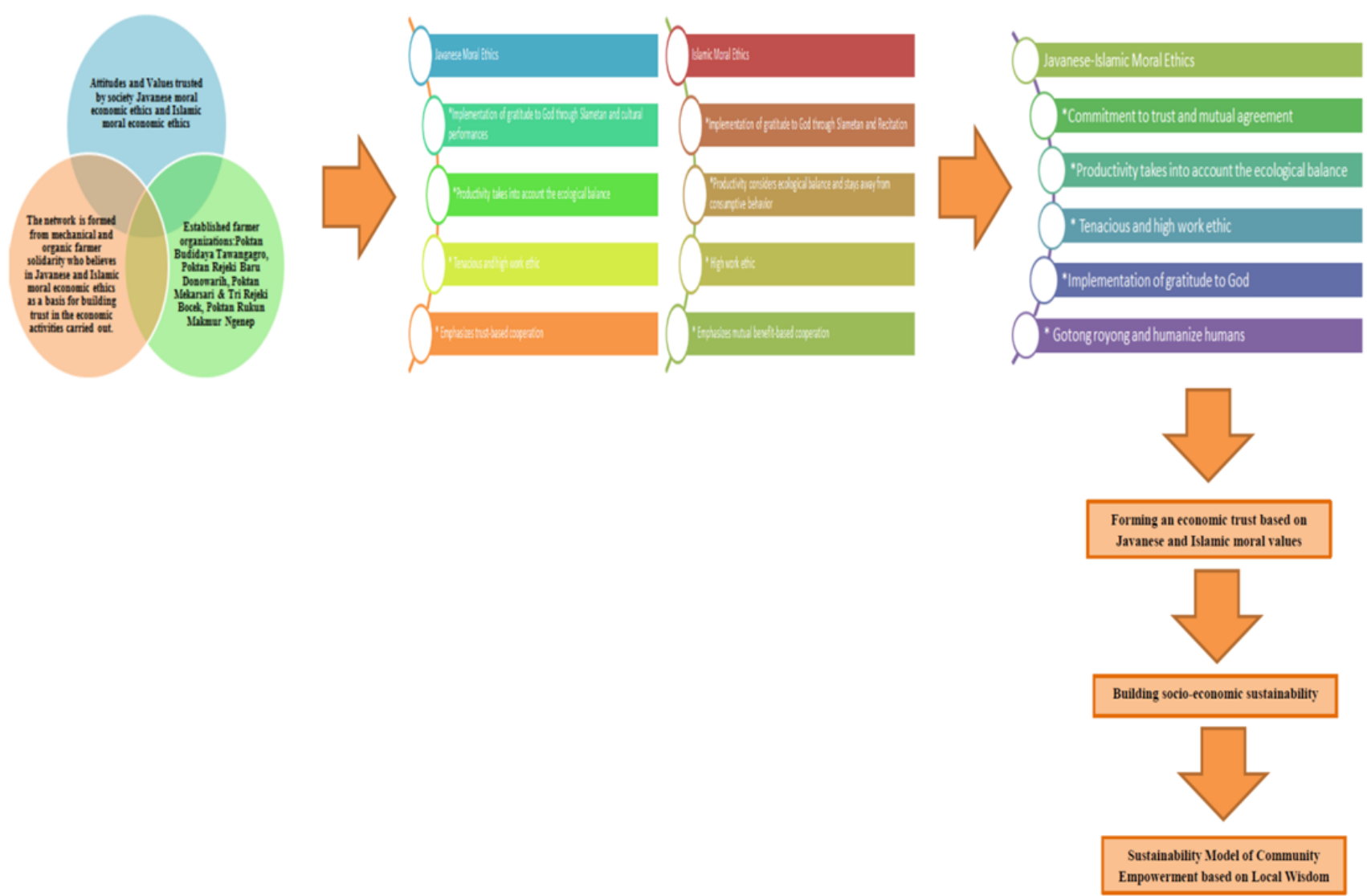

Source: Author's Illustration, 2021

Figure 1. The Motive of Arjuno Coffee Farmer's Economic Trust

Arjuno coffee farmers on the slopes of Karangploso have strong characteristics. Javanese and Islamic moral ethics are firmly held. Javanese and Islamic moral-ethical values influence to build of networks and institutions. They formed networks and institutions to build mutually beneficial relationships between farmers and other stakeholders involved. Trust in economic activity and interaction is closely held. Arjuno coffee farmers rely on creating socioeconomic benefits that individuals and groups feel so that economic morality is upheld by every actor in Arjuno's coffee economic interactions and activities (see Figure 1).

Coffee farmer Arjuno still firmly holds the attitude of "gak gelem di ndas-endasi," which is the basis of the economic trust motive. This attitude is the behavior of farmers who hold fast to local knowledge that they believe in and do not believe in people who are "rumongso iso" and "mitunani wong liya". The attitude of "romungso iso" is simply a bright person but does not have intelligent and cultured ways to explore the people he teaches. While the attitude of "mitunani wong liya", is simply a person who uses deception to harm others. In the coffee farming community of Arjuno, the philosophy of "gak gelem di ndas-endasi" is increasingly influenced by Javanese and Islamic moral ethics.

Reinforcing the facts in the field, taking the opinion of Mubyarto (2004), who said that people's coffee plantations and their coffee farmers have made economic rationality oriented to the application of morality-based economic humans, they apply in line with homo-ethics, religious and mystics. The application of homoethics can explain all three characteristics of homo-ethics, as follows: (a) charitable (pays 
attention to the interests of others), (b) a cooperative, honest and truthful person, (c) holds the trust, and (d) trust other people. All of them are moral stimuli where the role of religion and culture can suppress economic rationality to a maximum profit-oriented.

For informants A.TR and A.TB, attachment to the morality of Islam in the economic actions of coffee farmers. Islamic moral ethics is a form of devotion to religiosity. The character of the Islamic religion can lead people to get allocation and distribution to manage economic resources that prioritize benefits for others and closeness to God Almighty. Informants A.TR and A.TB revealed that coffee farming is an effort to be more trustworthy; the coffee selling price system controlled by middlemen made A.TR and A.TB feel the need to surrender every productive effort to God in a business coffee farm, whether profit or loss. The attitude of trustworthiness made A.TR and A.TB try to practice fair, patient, and honest values in maintaining their coffee farming business.

This fair value is reflected in attitudes and actions to treat farm laborers and intermediaries equally in economic interactions. Middlemen who use the nature of "mitunani wong liya" will find it challenging to approach Islamic capitalist farmers A.TR and A.TB because, for them, this trait has harmed and lost the trust they have for that person.

The value of patience is reflected as an indirect form of avoiding social conflict. Losses obtained from farming activities are often miserable. The price of red beans regulated by middlemen often does not match the price of red beans in the market. The orientation of coffee farmers selling red beans is not processed beans because it considers the capital turnover of their farming business. However, each year, farmers experience a difference in losses from selling red beans with processed beans by an average of 5 to d. 15 percent per hectare. A significant loss occurs because the system used is a wholesale system, not a grading system.

Furthermore, there are the last two values of the attitude of "Gak Gelem di ndas-endasi" which is influenced by religious morals, especially the morals of Islam, namely honesty and kinship. These two values are applied in social actions in Compensation and Recitation. A.TR and A.TB representatives of Islamic capitalist farmers said that in their farming income, there are still other people's poor rights that must be distributed in compensation, especially in the month of Suro (Muharram) every year. At the same time, the recitation can be done during regular meetings between farmers, which are always filled with tahlil, istighosah, and spiritual teachings from local missionaries; these patterns indirectly foster social awareness among coffee farmers.

"Gak Gelem diendas-endasi" attitude is influenced by cultural morals, especially Javanese morals. For KI, RN, and SP, coffee farming is the art of building relationships, namely the relationship between humans and the creator, nature, and the relationship between living things between humans-plants- animals are the same as ngaurip. For them, the balance of nature and the relationship between farmers must be the basis for maintaining their farming business. Nature is the main production factor in Javanese morals, while the relationship between farmers is the main foundation for building better socio-economic relations.

\section{Building an Incubation Model for Arjuno's Coffee Social Business Strengthening}

The application of Economic trust using Javanese-Islamic cultural values on Arjuno coffee farmers with inherent economic activities. There is a need for sustainable empowerment of Arjuno coffee farmers, within 9 years PPL and Social Entrepreneurs have done it, but the sustainability of empowering Arjuno coffee farmers with social businesses, here are some steps that can be taken:

First, Pre-Incubation Strengthening Social Business Based on Javanese-Islamic Culture. Motive description of Arjuno Coffee Farmer's Economic Trust. This description is the initial part of the sustainable process of empowering Arjuno coffee farmers, the Javanese-Islamic culture in the activities of Arjuno coffee farmers which is firmly held to be a reinforcement for the creation of welfare for Arjuno coffee farmers. 


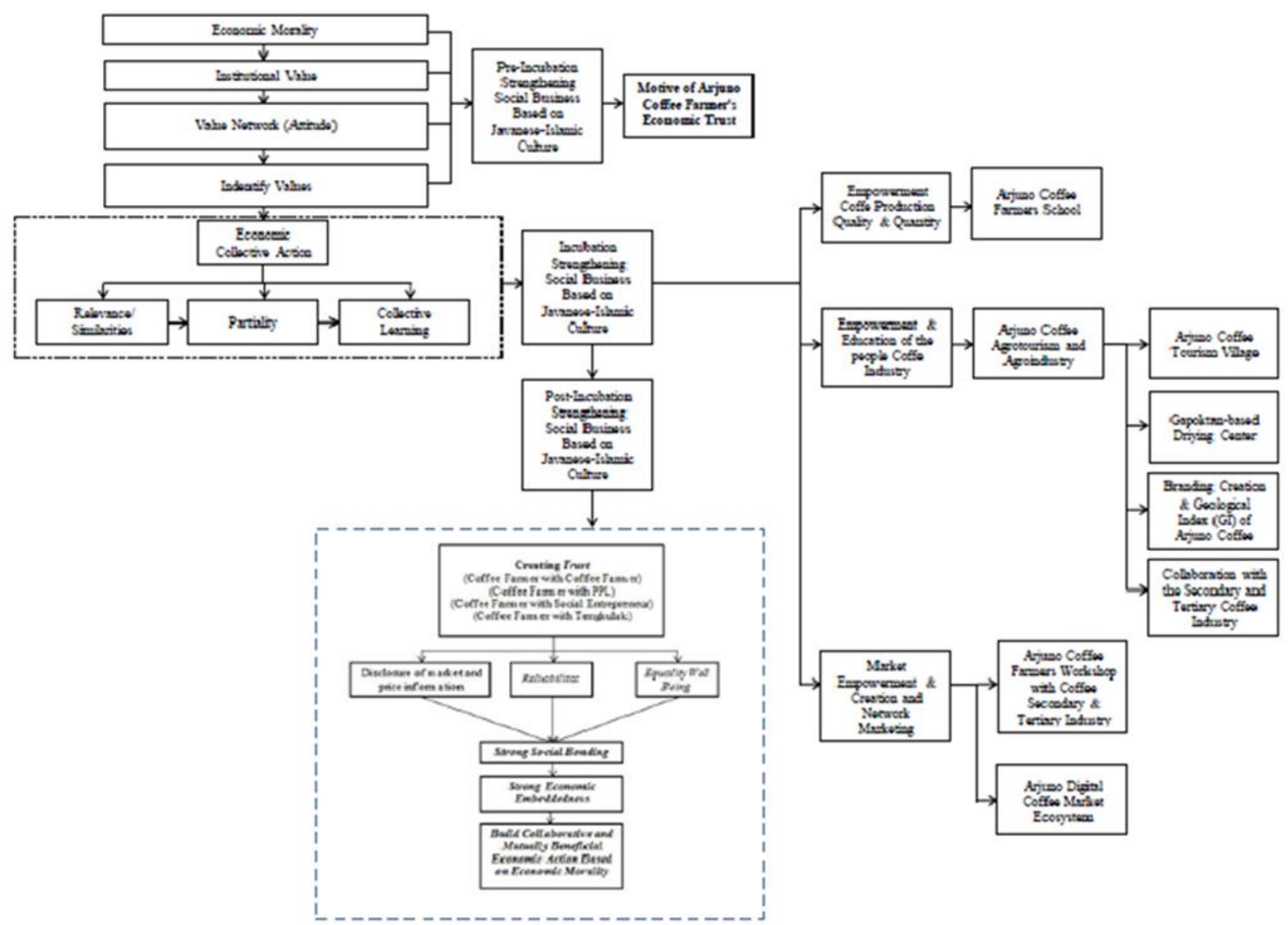

Source: Author's Illustration, 2021

Figure 2. Incubation Model for Arjuno's Coffee Social Business Strengthening

Second, Incubation Strengthening Social Business Based on Javanese-Islamic Culture. There are at least three processes for empowering Arjuno coffee farmers, which are carried out as follows:

a. Empowerment of Coffee Production Quality \& Quantity through the Arjuno Coffee Farmers School, parties outside Arjuno coffee farmers act as facilitators, and successful/assisted farmers in becoming driving farmers. The Arjuno Coffee Farmers School implements a curriculum with ecological and economic sustainability perspective. The preparation and implementation of the Arjuno Coffee Farmers School curriculum are carried out with the active involvement of Arjuno coffee farmers. So, the benefits can be felt directly if there is the active participation of beneficiaries because farmers Kopi Arjuno (beneficiaries) think they have implemented empowerment.

b. Empowerment \& Education of the People Coffe Industry. Empowerment \& Education of the People Coffee Industry. The implementation of Arjuno Coffee Agrotourism and Agroindustry is the main target. There are four targets of empowerment programs that need to be carried out: (1) Arjuno Coffee Tourism Village, the economic opportunities for tourism villages are very large for Arjuno coffee farmers in the future. Coffee and non-coffee-loving tourists, because psychologically tourists, domestic and foreign travelers prefer nature and educational tourism to unwind the urban activities they do; (2) Gapoktan-Based Drying Center, coffee products that have 
entered the drying process are higher than those that have not gone through the process, but the high cost of the drying process makes farmers not interested in selling their harvests using the drying process, so point 2 is a solution coffee farmers Arjuno to make the high cost of drying individually borne into a lower cost of drying as a group; (3) Branding Creation \& Geological Index (GI) of Arjuno Coffee, product branding affects the increase in sales of post-harvest products, strengthened by the fulfillment of the Geological Index as a benchmark for the quality and quantity of coffee harvested products that are recognized in the international market and; (4) Collaboration with the Secondary and Tertiary Coffee Industry, meeting the needs of the secondary and tertiary industries which are still an opportunity to be fulfilled by Arjuno coffee farmers. Moreover, the best quality of Arjuno Arabica coffee can be an attraction for the secondary and tertiary coffee industries.

c. Market Empowerment \& Creation and Network Marketing. There are two programs to empower Arjuno coffee farmers: (1) Arjuno Coffee Farmers Workshop with Secondary \& Tertiary Coffee Industry. Arjuno coffee farmers collaborate with PPL, sub-district government, and related agencies to initiate a workshop to provide information for Arjuno coffee farmers. It's about the cooperation scheme with the secondary and tertiary coffee industry and how the product standards are accepted by the secondary and tertiary coffee industries and the selling price standards that are determined. Secondary and tertiary coffee industries; (2) Arjuno Digital Coffee Market Ecosystem. Arjuno coffee farmers can collaborate with digital marketing practitioners to build an effective Arjuno coffee digital market ecosystem and provide more incredible economic benefits for Arjuno coffee farmers.
Third, Post-Incubation Strengthening Social Business Based on Javanese-Islamic Culture. The stages of empowerment to strengthen Arjuno's coffee social business can create trust in the economic activities of coffee farmers. Trust coffee farmers and stakeholders outside coffee farmers (PPL, social entrepreneurs, tengkulak, and other collaborating stakeholders) to create collaborative and mutually beneficial economic action based on economic morality. This will increase the economic benefits of Arjuno coffee farmers directly or indirectly.

\section{CONCLUSIONS}

Coffee farmer Arjuno upholds JavaneseIslamic morals as a guide in implementing PreIncubation Strengthening of Javanese-Islamic Culture-Based Social Business. Of course, in building the Incubation for Strengthening Social Enterprises Based on Javanese-Islamic Culture, there are three programs, namely: (a) Empowerment of Coffee Production Quality \& Quantity (Arjuno Coffee Farmers School); (b) Empowerment \& Education of the People's Coffee Industry. Empowerment \& Education of the People's Coffee Industry, (Arjuno Coffee Tourism Village, Drying Center Based on Gapoktan, Branding Creation \& Geological Index (GI) of Arjuno Coffee and Cooperation with Secondary and Tertiary Coffee Industries) and; (c) Empowerment \& Creation of Markets and Marketing Networks (Arjuno Coffee Farmers Workshop with Secondary \& Tertiary Coffee Industry and Arjuno Digital Coffee Market Ecosystem). We expect Post-Incubation Social Business Strengthening Based on Javanese-Islamic Culture to create trust in the economic activities of Arjuno coffee farmers so that increased welfare and collaboration can directly or indirectly benefit Arjuno coffee.

\section{ACKNOWLEDGMENT}

Thank you to all those who have helped with this research and community service. Indonesian coffee farmers have the right to be more prosperous and take advantage of the collaborative ecosystem. 


\section{BIBLIOGRAPHY}

Granovetter, M. (2005). The Impact of Social Structure on Economic Outcomes. Journal of Economic Perspectives. Vol.19. Number 1 .

Granovetter, M. (1985). - Economic Action and Social Structure: The Problem of Embeddednessll. American Journal of Sociology. Vol. 91, pp.481-510.

Granovetter M, Swedberg R. (1992). The Sociology of Economic Life. USA: Westview Press.

Ostrom E and Ahn TK. 2009. The meaning of social capital and its link to collective action. Handbook of Social Capital. The Troika of Sociology, Political Science and Economics. Gert Tinggaard Svendsen and Gunnar Lind Haase Svendsen (Editors). UK: Edward Elgar.

Skovdal,Morten and Cornish,Flora .2015. Qualitative Research for Development A Guide for Practitioners.UK:Practical Action Publishing. 